\title{
DETERMINATION OF SOCIAL SUSTAINABILITY LEVEL WITH QUANTITATIVE INDICATORS: A RESEARCH ON NON-METALLIC MINERAL COMPANIES LISTED ON BORSA ISTANBUL
}

DOI: 10.17261/Pressacademia.2018.957

JBEF- V.7-ISS.3-2018(8)-p.295-308

\author{
Cuneyd Ebrar Levent \\ Istanbul Aydin University, Institute of Social Sciences, Istanbul, Turkey. \\ cuneydlevent@aydin.edu.tr, ORCID: 0000-0003-1494-3029
}

Date Received: July 20, 2018

Date Accepted: September 22, 2018

\section{To cite this document}

Levent, C. E. (2018). Determination of social sustainability level with quantitative indicators: a research on non-metallic mineral companies listed on Borsa Istanbul. Journal of Business, Economics and Finance (JBEF), V.7(3), p.295-308.

Permemant link to this document: http://doi.org/10.17261/Pressacademia.2018.957

Copyright: Published by PressAcademia and limited licenced re-use rights only.

\begin{abstract}
Purpose- The purpose of this research, is to create a framework of social sustainability expressed as quantitative indicators and to analyze the social sustainability level of the companies listed on Borsa Istanbul (BIST) in non-metallic mineral industry sector.

Methodology- In this study, social sustainability is measured by 8 categories and 22 criteria considering the literature. Social sustainability data were obtained from publicly available sources in 2017, such as the annual report, the corporate governance compliance report, and the minutes of the general meeting. The social sustainability levels of companies are analyzed by frequency analysis technique. The calculated category and criteria scores were also examined on the basis of the market values of the companies.

Findings- As a result of the research, the level of social sustainability in the non-metallic mineral industry was determined as 46.97 . Within the social sustainability categories, the highest score was found in the ethics category, and the lowest score was found in the philanthropy category The results are also analyzed according to the market capitalization of companies. According to the results, in all social sustainability categories, companies with high market value have a higher social sustainability score than others.

Conclusion- The results show that the social sustainability level is inadequate for the non-metallic mineral industry. In general, it is thought that this study contributes to the literature on social sustainability by providing a new perspective by suggesting measurable, comparable criteria.
\end{abstract}

Keywords: Social sustainability, social responsibility, corporate governance, disclosure, market value.

JEL Codes: M14, Q01, O16

\section{INTRODUCTION}

Although sustainability is generally defined differently in various disciplines and there is no consensus on it, sustainability generally refers to protecting assets or resources and moving it to the future. In the early definitions of sustainability, the concept was often associated with sustainable development. According to the definition of the United Nations World Commission on Environment and Development, also known as the Brundtland Report, sustainable development is a development that ensures that meets the needs of the present without compromising the ability of future generations to meet their own needs (WCED, 1987). The sustainable development paradigm focuses on limiting the consumption of economic, social and environmental resources, contributing to the prosperity of present and future generations, and exploring how development is applicable to local, regional, national and international levels on the basis of political will (Glavič and Lukman, 2007).

The consideration of sustainability at the business scale is described as corporate sustainability (Salzman et al., 2005). The concept of corporate sustainability is closely related to the stakeholder approach. Stakeholder theory considers the interests of all stakeholders that affect the achievement of company goals or that are affected by company activities (Freeman, 2010). The stakeholder approach argues that a company is responsible not only to shareholders but also to all stakeholders, and rejects the 
view of Friedman (1982) that "there is one and only one social responsibility of business to increase its profits". Corporate sustainability also includes a perspective on continuity and future beyond the concepts of stakeholder approach and social responsibility.

Corporate sustainability has economic, environmental and social dimensions (WCED, 1987; Searcy and Elkhawas, 2012; Docekalová and Kocmanová, 2016.) Economic sustainability refers to the economic performance of a company while maintaining its current activities and ensuring that these activities continue in the future. Besides, the characteristics of the industry in which the company operates and the macroeconomic developments are examined in economic sustainability. Economically sustainable companies can be described as companies that provide a return above average to their shareholders while guaranteeing sufficient cash flow when the firm needs it (Dyllick and Hockerts, 2002). The second component of corporate sustainability is environmental sustainability. Environmental sustainability is related to avoiding business practices that damage human life and the ecosystem in the production process of goods and services. Environmental sustainability includes basic issues such as water, air, soil and noise pollution prevention, and parameters such as climate change, biodiversity, renewal capacity, reusing, recycling and carbon footprint (Pullman et al., 2009; Morelli, 2011; Searcy and Elkhawas, 2012; D'Amato et al., 2015). Social sustainability is the third dimension of corporate sustainability. Social sustainability can be defined as being respectful to stakeholders, such as employees, customers, suppliers and the society, based on human rights fulfilling the responsibilities and making it permanent. Just as it is in other components of corporate sustainability, social sustainability is also essential to consider not only today but tomorrow (future generations).

In this study, social sustainability is considered at the business level within the context of corporate sustainability. In the second section of this paper after this introduction section, literature review on social sustainability is given. In the literature section, the scope of social sustainability and the studies carried out in this area are presented. Also, the indicators that represent social sustainability are addressed. Then, a research on determination of the level of social sustainability is taking place. In the final section, conclusions and suggestions are included. In summary, the following questions are searched for in this paper:

1-What should be measurable and comparable indicators representing social sustainability?

2-What is the level of social sustainability both in total and in categories in the industry covered by the research?

3-Does the market value of companies make a difference on social sustainability?

\section{LITERATURE REVIEW}

Social sustainability addresses how social problems can be managed to survive in the long term (Mani et al., 2016). McKenzie (2004) identified social sustainability as a process within communities that could provide a positive condition. According to the author, this process can be completed by realizing such indicators as "equality in basic services", "equality between generations", "consideration of the positive aspects of different cultures", "political participation of citizens", "the presence of sense of community ownership and responsibility" and "establishment of a system for transmitting awareness of social sustainability between generations". McKenzie also emphasized the importance of the existence of mechanisms for a community to collectively identify its strengths and needs, in the definition of social sustainability.

These definitions and explanations show that social sustainability is an approach which has community and organizational culture dimension. As stated in the Brundtland Report (WCED, 1987), for sustainability to take place, priority needs to be given to people and countries lacking in meeting basic needs. Three out of 17 goals (hunger, health and clean water) stated at the United Nations Sustainable Development Goals (UN, 2016) consist of tangible elements that must be urgently addressed. Failure to meet these vital needs will not make other elements meaningful. Equality must be ensured after basic needs are met. This can be manifested in economic indicators such as income inequality between countries, regions or communities, as well as racial, linguistic, religious or gender discrimination. However, there is also the time component of the concept of equality. As mentioned earlier equality in the sustainability approach includes future dimension. In addition the state or international organizations should try to ensure equality for current and future generations.

In the perspective of sustainable development, components of social sustainability such as equality, people, society, and social responsibility should address numerical and as measurable as possible, not with ambiguous expressions or wishes. Therefore, all these elements need to be defined correctly. The identification of measurable targets such as "proportion of population living below \$ 1 a day", "adult literacy rate", "percent of population with access to primary health care facilities" will certainly contribute to ensuring social sustainability comparing to ambiguous statements such as "poverty problem will be resolved soon".

However, it cannot be enough to achieve social sustainable development goals on a global scale or country scale. Business enterprises, one of the most important elements of the economic system, should also contribute to this issue.

Business relations between companies and stakeholders (e.g. employees, suppliers) determine the scope of social sustainability. As an organization, businesses and employees are mutually dependent. This dependency occurs with a vertical and horizontal 
communication process. Van Marrewijk (2003), stated that; businesses are supporting them by establishing a vertical relationship with their employees in order to achieve their goals, and they are constantly interacting with each other at the same time by establishing horizontal relations with their stakeholders. Concepts such as employee rights and customer satisfaction can be regarded as components of social sustainability, which is the result of these relationships.

The stakeholders of the companies are not only employees and customers. Freeman (2010) divides the stakeholders into internal and external stakeholders; internal stakeholders include company owners, employees, customers, suppliers; and external stakeholders exemplify the state, competitors, consumer associations, environmental organizations, the media and various interest groups. The most important stakeholder in the social sustainability approach is society. A company that respects employee rights and meets the principles of occupational health and safety actually fulfills some of its responsibilities. From this point of view, concepts such as human rights, health, gender equality can be considered as important elements of social sustainability (Ahmadi et al., 2017). The problem of quantifying the concepts encountered in sustainable development parameters can also be a topic of social sustainability at the business level. Besides, some of the elements of economic, environmental and social sustainability are related to each other. $\mathrm{CO} 2$ emissions of a cement plant and wastewater discharge in $\mathrm{m} 3$ are accepted as environmental sustainability criteria, but can also be interpreted as an element of social sustainability.

This confusion can only be achieved by defining sustainability criteria and standardizing them. There are various organizations operating on the global scale in this regard. One of the most important of these organizations is the Global Reporting Initiative (GRI). GRI is an organization that develops standards for the economic, environmental and social components of sustainability (Global Reporting, 2018). GRI also identifies these standards and publishes them on how to implement or report these standards.

Globally, especially public companies annually report on sustainability reports based on the GRI methodology. In Turkey, there are also many companies which have been preparing sustainability reports. In Turkey, 181 corporate sustainability reports were prepared between the years 2005-2014, of which 130 were arranged according to the GRI methodology (Önce et al., 2015).

GRI addresses social sustainability in four categories. These categories consist of "Labor Practices and Decent Work", "Human Rights", "Society" and "Product Responsibility" (Figure 1).

\section{Figure 1: Social Sustainability Categories According to GRI Methodology}

\begin{tabular}{|c|c|c|c|c|}
\hline Category & Social & & & \\
\hline $\begin{array}{l}\text { Sub- } \\
\text { Categories }\end{array}$ & $\begin{array}{l}\text { Labor Practices and } \\
\text { Decent Work }\end{array}$ & Human Rights & Society & Product Responsibility \\
\hline Aspects "II & $\begin{array}{l}\text { - Employment } \\
\text { - Labor/Management } \\
\text { Relations } \\
\text { - Occupational Health } \\
\text { and Safety } \\
\text { - Training and Education } \\
\text { - Diversity and Equal } \\
\text { Opportunity } \\
\text { - Equal Remuneration for } \\
\text { Women and Men } \\
\text { - Supplier Assessment for } \\
\text { - Labor Practices } \\
\text { - Labor Practices } \\
\text { Grievance Mechanisms }\end{array}$ & $\begin{array}{l}\text { - Investment } \\
\text { - Non-discrimination } \\
\text { - Freedom of Association } \\
\text { and Collective } \\
\text { Bargaining } \\
\text { - Child Labor } \\
\text { - Forced or Compulsory } \\
\text { Labor } \\
\text { - Security Practices } \\
\text { - Indigenous Rights } \\
\text { - Assessment } \\
\text { - Supplier Human Rights } \\
\text { Assessment } \\
\text { - Human Rights } \\
\text { Grievance Mechanisms }\end{array}$ & $\begin{array}{l}\text { - Local Communities } \\
\text { - Anti-corruption } \\
\text { - Public Policy } \\
\text { - Anti-competitive } \\
\text { Behavior } \\
\text { - Compliance } \\
\text { - Supplier Assessment for } \\
\text { Impacts on Society } \\
\text { - Grievance Mechanisms } \\
\text { for Impacts on Society }\end{array}$ & $\begin{array}{l}\text { - Customer Health and } \\
\text { Safety } \\
\text { - Product and Service } \\
\text { Labeling } \\
\text { - Marketing } \\
\text { Communications } \\
\text { - Customer Privacy } \\
\text { - Compliance }\end{array}$ \\
\hline
\end{tabular}

Source: Global Reporting Initiative G4 Sustainability Reporting Guidelines (Global Reporting, 2013)

According to the GRI methodology, social sustainability category consists of sub-categories, which include several aspects. In these aspects, companies are required to submit information, declarations or numerical information instead of ambiguous expressions. For example, the "Human Rights" sub-category consists of 10 aspects. In the aspect Non-Discrimination, "the total number of incidents of discrimination during the reporting period" criterion is included and it is requested that the results of the investigation against this case and the remediation plans applied are reported. Similarly, sub-other categories include such quantitative, measurable, and comparable indicators. 
Sustainability reports based on GRI methodology in the literature and the results obtained from these reports have been subject to many researches (Hedberg and von Malmborg, 2003; Skouloudis et al., 2010; Toppinen et al., 2011). However, the fact that the GRI methodology is very comprehensive, especially in developing countries, even for many large companies, leads to these companies avoiding the preparation of a sustainability report. This situation only causes GRI-based research to exclude other companies so that real sustainability levels can not be determined. Therefore, many researchers have tried to measure sustainability with the scales they have developed, covering all companies.

Hutchins and Sutherland (2008) proposed a general strategy for social sustainability measures and identified various indicators in their work on measuring social sustainability and applying them to supply chain decisions. These indicators were; "labor equity", "healthcare", "safety" and "philanthropy". The authors demonstrated how these indicators could be applied to supply chain decision making processes.

Pullman et al. (2009) investigated the environmental and social sustainability practices and performance outcomes of companies in the food sector in the United States. In the research social sustainability was addressed in five criteria: quality of life, skill development, job satisfaction, fair compensation and employment status verification. The results show that the food industry managers perceive the direct and indirect effects of sustainability practices on performance.

Mani et al. (2016) from India took into consideration the dimensions of social sustainability not only for the central company but also for the first-tier suppliers and customers. In the research, social sustainability in manufacturing companies was examined in 11 main categories as society, health and safety, ethics, equity, labour rights, philanthropy, child and bonded labour, wages, education and housing. In the study, the results were analyzed by frequency analysis. One of the remarkable results of the survey is that the discrimination is high at a rate of $70 \%$.

Bamgbade et al. (2017) examined the relationship between organizational innovation and social sustainability in Malaysia's construction sector firms, using seven criteria representing social sustainability performance in the construction sector. These were health and safety, customer comfort and satisfaction, community welfare, accessibility, social involvement, workers' welfare and aesthetics. The authors found a strong relationship between innovation and social sustainability performance.

Ahmadi et al. (2017) investigated the social sustainability practices in the supply chains in their studies covering firms in the manufacturing industry in Iran. In the study, social sustainability was determined by the criteria of "work health and safety", "training education and community influence", "contractual stakeholders' influence", "occupational health and safety management system", "the interests and rights of employees", "the rights of stakeholders", "information disclosure" and "employment practices".

Mani et al. (2018) developed taxonomy on social sustainability practices in companies. The authors studied a sample of 55 manufacturing industry companies listed in the Portuguese Stock Exchange. Social sustainability was researched in 21 criteria such as safety, human rights, product responsibility, philanthropy, education, unethical practices, working standards, skills development and child labor. The results of the research were presented by frequency analysis.

Popovic et al. (2018) pointed out that there was lack of information for the social assessment. In this context they proposed 31 quantitative social sustainability indicators to evaluate of the whole supply chain. The authors developed these indicators based on literature review and validated by a content analysis of 141 sustainability reports. Some of the indicators used in the research included human rights implementation, employee wellfare and occupational health and safety. The authors emphasized that the proposed indicators could be used for both performance assessment, as well as for periodical monitoring of the supply chains.

\section{DATA AND METHODOLOGY}

\subsection{Scope of the Research}

The scope of the research constitutes companies operating in non-metallic mineral industry, which are listed in the Borsa Istanbul (BIST). At present, BIST has created a separate Non-metallic Mineral Industrial Index (XTAST) for companies in this sector. Before selecting companies, the company list in the XTAST index was compared with the list published by the Public Disclosure Platform (KAP). Since it is more comprehensive, the list published by the KAP was taken as a basis for the research.

Non-metallic mineral industry has an important place in Turkey's economy. The industry employs thousands of people and also makes a large contribution to the growth of Turkey's economy. The most important sector in this industry is the cement sector. When analyzed cement production between the years 2012-2017, Turkey was the largest producer in Europe, while in the world ranked at fifth, after China, India, the United States and Vietnam (Statista, 2018). The other sector included in the non-metallic mineral industry is the glass production sector. The glass production sector requires high capital investment. Outputs of the industry are the inputs of the basic industries such as automotive, construction, white goods, cosmetics, food, medicine. With 916 million USD export, the sector is located an important position in Turkey (Denizli Cam, 2018). Besides cement and glass, 
non-metallic mineral products include ceramic and lime production. The distribution of the companies in the research according to the sub-sectors is given in Figure 2.

Figure 2: Distribution of Companies in the Research by Sub-sectors

Number of Companies

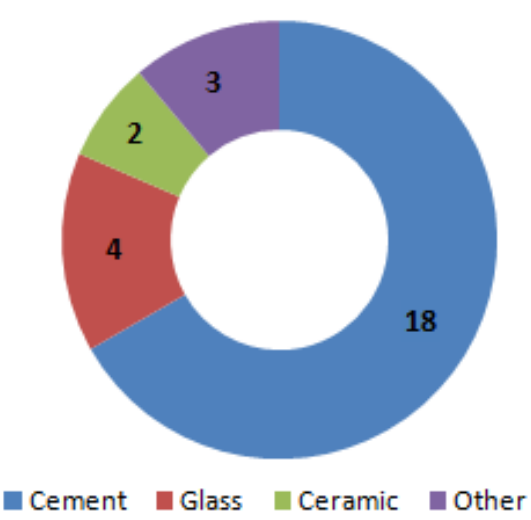

Market Capitalization

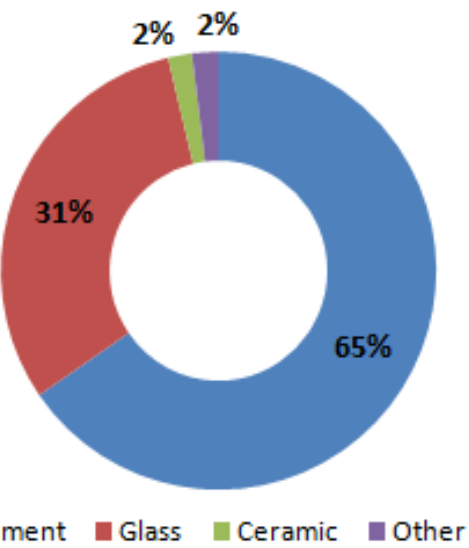

As of the end of 2017, there are 27 non-metallic mineral product companies which are listed in Borsa Istanbul. All of these companies have been included in the research and no companies have been eliminated. The list of companies is given in Appendix 1.

As presented in Appendix 1, non-metallic mineral product companies have an asset size of 32.9 billion TL and a market value of 25.6 billion TL. The data are based on financial statements and market values published at the end of 2017. The first three companies with the highest market value are Trakya Cam, Aslan Çimento and Akçansa Çimento.

\subsection{Data and Methodology}

As stated in previous chapters, the selection of criteria is a critical issue, while determining the level of social sustainability. Because of the lack of a generally accepted scale for social sustainability, the development of criteria has been preferred. In this context, the methodology applied by Popovic et al. (2018) was followed in the setting of the criteria. According to this, firstly literature was reviewed and social sustainability indicators were defined, then these indicators were classified and categories were created. In the next step, all the indicators were revised and some indicators were eliminated. In the development step, each criterion was clearly defined to avoid misinterpretation. It was also checked whether the social sustainability criteria were relevant, understandable, measurable and accessible. Finally, with the application step, the design of the indicators completed. In line with this methodology, social sustainability is divided into 8 main categories (Table 1 ).

Table 1: Social Sustainability Categories Selected for the Assessment.

\begin{tabular}{ll}
\hline Category & Reference \\
\hline $\begin{array}{l}\text { Combating bribery and } \\
\text { corruption (BC) }\end{array}$ & (Delai and Takahashi, 2013; Global Reporting, 2013; Mani et al. , 2016; Engida et al., \\
\hline Human rights (HR) & (Global Reporting, 2013; Engida et al., 2018; Mani et al., 2018; Popovic et al., 2018) \\
\hline Employee rights (ER) & (Pullman et al., 2009; Global Reporting, 2013; Mani et al., 2016; Ahmadi et al., 2017; \\
\hline Ethics (ET) & Bamgbade et al., 2017; Mani et al., 2018; Popovic et al., 2018) \\
\hline Education (ED) & (Mani et al., 2016; Engida et al., 2018) \\
\hline Philanthropy (PH) & (Global Reporting, 2013; Mani et al., 2016; Ahmadi et al., 2017; Mani et al., 2018) \\
\hline $\begin{array}{l}\text { Occupational health and safety } \\
\text { (OH) }\end{array}$ & (Mani et al., 2016; Mani et al., 2018) \\
\hline Product responsibility (PR) & Mani et al., 2018; Popovic et al., 2018) \\
\hline
\end{tabular}

Below these categories are the criteria that represent social sustainability. Social sustainability in this research is measured by 22 criteria according to the categories determined based on the literature. Care has been taken to ensure that these criteria have quantitative, measurable and comparable qualities. Because a majority of the social issues are subjective and qualitative (Hutchins and Sutherland, 2008). For example, "philanthropy issue" can cause different interpretations. 
What is sought in the criteria needs to be clearly stated. Thus, a research form has been developed, which is given in Table 2 . Information on whether the 27 companies provided the relevant social sustainability criteria within the scope of the research were obtained from public sources because all companies are publicly listed companies. In this research, the sources used to determine the level of social sustainability of companies are as follows:

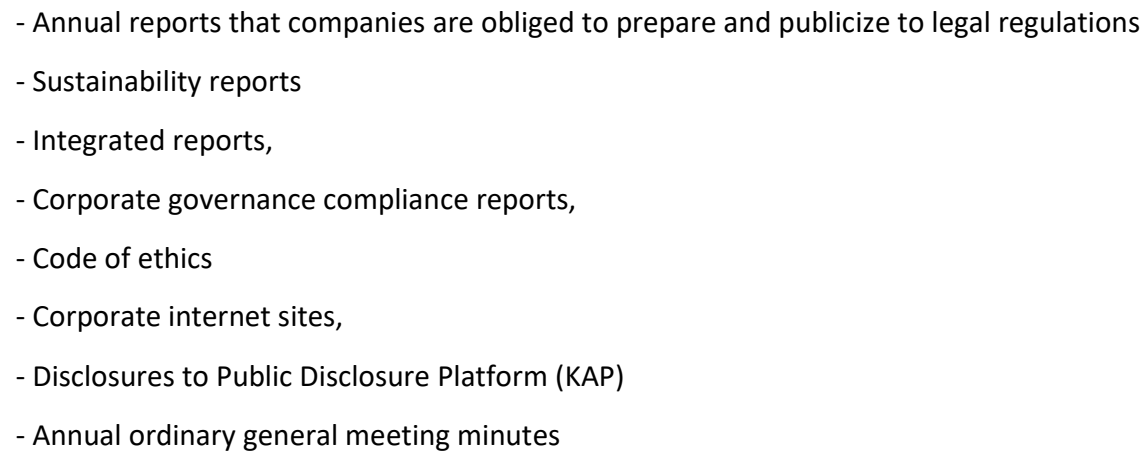

It has been investigated by public sources that each company fulfills the social sustainability criteria given in Table 2 . If the company has provided the relevant criterion, it receives 1 value for the criterion if it can not, it is given 0 value, so that the data is quantified. For example, there are two criteria in the "Combating Bribery and Corruption" category. In the criterion BC1, it is questioned whether the company's public resources refer to a statement on bribery and corruption. This is explored by checking all the public sources one by one. If such an explanation is found, the BC1 variable has a value of "1", otherwise "0". Similarly, this query is repeated for all criteria.

Table 2: Social Sustainability Research Form

\begin{tabular}{|c|c|}
\hline Criteria Code & Criteria Description \\
\hline \multicolumn{2}{|c|}{ CATEGORY: COMBATING BRIBERY AND CORRUPTION (BC) } \\
\hline $\mathrm{BC1}$ & Is there any disclosure on anti-bribery and anti-corruption? \\
\hline $\mathrm{BC} 2$ & Is the company's "anti-bribery and anti-corruption policy" disclosed? \\
\hline \multicolumn{2}{|c|}{ CATEGORY: HUMAN RIGHTS (HR) } \\
\hline HR1 & $\begin{array}{l}\text { Is there any disclosure that there is no discrimination among employees? (age, race, language, religion, } \\
\text { ethnicity) }\end{array}$ \\
\hline HR2 & Is there any disclorure that there is no gender discrimination among employees? \\
\hline HR3 & Is there any disclorure about child labor risk? \\
\hline \multicolumn{2}{|c|}{ CATEGORY: EMPLOYEE RIGHTS (ER) } \\
\hline ER1 & Is there any disclosure that employees are provided with healthy working conditions? \\
\hline ER2 & Is there any disclosure that objective criteria have been applied in recruitment \& promotion? \\
\hline ER3 & Is there any disclosure that objective criteria have been applied to compensation? \\
\hline ER4 & Are detailed information disclosed on employee training and career development? \\
\hline ER5 & Is the company's "human resources policy" disclosed? \\
\hline \multicolumn{2}{|c|}{ CATEGORY: ETHICS (ET) } \\
\hline ET1 & Is the company's "code of ethics" disclosed? \\
\hline ET2 & Are grievance mechanisms for ethics established? \\
\hline \multicolumn{2}{|c|}{ CATEGORY: EDUCATION (ED) } \\
\hline ED1 & Is the level of education of employees disclosed? \\
\hline ED2 & Does the company cooperate with educational institutions (university, high school, etc.)? \\
\hline ED3 & Is there any disclosure on employees' training with numerical data ? (e.g. training hours) \\
\hline \multicolumn{2}{|c|}{ CATEGORY: PHILANTHROPY (PH) } \\
\hline $\mathrm{PH} 1$ & Are donations to civil society organizations disclosed in details? \\
\hline $\mathrm{PH} 2$ & Are donations to educational institutions disclosed in details? \\
\hline \multicolumn{2}{|c|}{ CATEGORY: OCCUPATIONAL HEALTH and SAFETY $(\mathrm{OH})$} \\
\hline $\mathrm{OH} 1$ & Has the company OHSAS 18001 certificate? \\
\hline $\mathrm{OH} 2$ & Are numerical data on work accidents disclosed? \\
\hline \multicolumn{2}{|c|}{ CATEGORY: PRODUCT RESPONSIBILITY (PR) } \\
\hline PR1 & Are customer satisfaction survey results shared with the public? \\
\hline PR2 & Are the quality certificates of the company disclosed? \\
\hline PR3 & Is the company's information security policy diclosed? \\
\hline
\end{tabular}


After searching for the existence of 22 criteria for a company, this method has been applied to other companies ( 27 companies in total) as part of the research. After all these operations were completed, a data set consisting of 594 data (22 criteria x 27 companies) was obtained. Since the public source of companies (especially annual reports and corporate internet sites) is not standardized, a large number of reports and documents had to be examined for each criterion.

After the data set was created, the social sustainability level was calculated based on the criteria first and then on the category basis. The social sustainability levels were actually analyzed by frequency analysis as they are similar studies in the literature. But in this study, the level was also calculated on category basis.

Criteria-based social sustainability level is calculated as follows:

$$
\mathrm{SSL}_{\mathrm{cr}}=\left(\left(\sum_{i=1}^{\mathrm{n}} \mathrm{X}_{\mathrm{i}}\right) / \mathrm{n}\right) \cdot 100
$$

where

$$
\begin{aligned}
& -\mathrm{SS}_{\mathrm{cr}}=\text { social sustainability level of the criteria, range } 0-100, \text { the higher the better (criteria score) } \\
& -\mathrm{i}=\text { company subscript } \\
& -\mathrm{n}=\text { number of companies }(\mathrm{n}=27) \\
& -\mathrm{X}=\text { The value of the relevant criteria }(0 \text { or } 1)
\end{aligned}
$$

The category-based social sustainability level is calculated as follows:

$$
\mathrm{SSL}_{\mathrm{ct}}=\left(\left(\sum_{\mathrm{j}=1}^{\mathrm{m}} \sum_{\mathrm{i}=1}^{\mathrm{n}} \mathrm{X}_{\mathrm{i}}\right)\right) \cdot 100 /(\mathrm{n} \cdot \mathrm{m})
$$

where

- $\mathrm{SSL}_{\mathrm{ct}}=$ social sustainability level of the category, range $0-100$, the higher the better (category score)

$$
\begin{aligned}
& -i=\text { company subscript } \\
& -j=\text { category subscript } \\
& -n=\text { number of companies }(n=27) \\
& -m=\text { number of categories } \\
& -X=\text { The value of the relevant criteria in the category ( } 0 \text { or } 1)
\end{aligned}
$$

For calculation of the social sustainability level of the industry, the same method in the category score was applied. While the category score and the industry score were calculated, the criteria were not assigned different weights, and each criterion was given equal weight.

The results of the research were also examined on the basis of market values of social sustainability level. In this context, companies were divided into two, with market values greater than or equal to 1 billion TL and less than 1 billion TL. The market value was calculated by multiplying the number of stocks and the price traded by the stock. Price data was obtained from the Borsa Istanbul (BIST) and stock data from the Public Disclosure Platform (KAP). All of the financial information was used by the end of 2017 financials of companies.

\section{FINDINGS AND DISCUSSIONS}

With the methods described in the previous section, the social sustainability levels of companies were first calculated. The frequency distributions resulting from these calculations are given in Table 3. 
Table 3: Frequency of Social Sustainability Scores of Companies

\begin{tabular}{lcc}
\hline Social Sustainability Score & Frequency & Percentage \\
\hline $90-100,00$ & 1 & $3,70 \%$ \\
$80-89,99$ & 3 & $11,11 \%$ \\
$70-79,99$ & 4 & $14,81 \%$ \\
$60-69,99$ & 3 & $11,11 \%$ \\
$50-59,99$ & 3 & $11,11 \%$ \\
$40-49,99$ & 3 & $11,11 \%$ \\
$30-39,99$ & 1 & $3,70 \%$ \\
$20-29,99$ & 5 & $18,52 \%$ \\
$10-19,99$ & 2 & $7,41 \%$ \\
$0-9,99$ & 2 & $7,41 \%$ \\
\hline Total & 27 & $100,00 \%$ \\
\hline
\end{tabular}

It is determined that only 1 out of the 27 companies has a social sustainability score above 90 . On the other hand, it is seen that the score of 2 companies is below 10. The highest frequency is in the range of 20-29.99. The results given in Table 3 show that the frequencies are relatively balanced, not concentrated in a certain range. The social sustainability score of one third of the companies is below 30, and the score of about half is below 50. Considering that all these companies have thousands of shareholders and are relatively large companies, it can be said that this result is inadequate in terms of social sustainability.

In Table 4, the social sustainability levels of companies in the non-metallic mineral industry are analyzed on a category basis. The highest category score is in the ethics category with 64.81, followed by human rights with 62.96 and occupational health and safety with 57.41. It has been determined that there is no category other than these three categories with a category score higher than 50.

Table 4: Results of Social Sustainability Scores Based on Category

\begin{tabular}{llc}
\hline Category Code & Category Name & Category Score \\
\hline BC & Combating bribery and corruption & 37,04 \\
HR & Human rights & 62,96 \\
ER & Employee rights & 47,41 \\
ET & Ethics & 64,81 \\
ED & Education & 37,04 \\
PH & Philanthropy & 20,37 \\
OH & Occupational health and safety & 57,41 \\
PR & Product responsibility & 45,68 \\
\hline & Social Sustainability Score (industry overall) & 46,97 \\
\hline
\end{tabular}

The lowest scoring category is the philanthropy category with 20.37. The other two low-scoring categories are education and the bribery and corruption with 37.04 scores. The score of product responsibility category is 45.68 and the employee rights category with 47.41 score, both scores are below the 50 level.

It should be emphasized that the ethics category takes the first place. All of the publicly listed companies in Turkey have to prepare and disclose corporate governance compliance report to the public. In corporate governance compliance reports, it is recommended that companies disclose code of ethics, and if they do not, they have to explain the reasons. It should be noted that even though there are legal requirements, 64.81 scoring in the study is not actually inadequate.

The lowest scoring philanthropy category, in fact, refers to the perspective in this study. That is, in the criteria in this category, companies were not asked whether they participated in social responsibility activities. Instead, the study investigate the details of the philanthropic activities of the companies. Approximately $80 \%$ of companies were found to refrain from disclosing donations in detail. When the annual reports of the companies are examined for this study, it turns out that the companies are not very honest about philanthropy. It is seen that some of the companies have included their social responsibility activities in previous years in the annual reports of the year 2017 as well.

In Table 5, the social sustainability levels of companies are given in terms of both category and market value. The companies in the non-metallic mineral industry are divided into two groups considering their market value. The total social sustainability score of the group of companies with a market value of more than 1 billion TL is 63.13 whereas it is 38.89 in companies whose market value is less than 1 billion TL. 
Table 5: Results of Social Sustainability Scores Based on Category and Market Value

\begin{tabular}{llcc}
\hline Category & \multirow{2}{*}{ Code } & Category Code & \multicolumn{2}{c}{ Category Score } \\
\cline { 3 - 4 } & & Market Value $<1$ billion TL & Market Value >= 1 billion TL \\
\hline BC & Combating bribery and corruption & 27,78 & 55,56 \\
HR & Human rights & 59,26 & 70,37 \\
ER & Employee rights & 37,78 & 66,67 \\
ET & Ethics & 58,33 & 77,78 \\
ED & Education & 25,93 & 59,26 \\
PH & Philanthropy & 19,44 & 22,22 \\
OH & Occupational health and safety & 41,67 & 88,89 \\
PR & Product responsibility & 38,89 & 59,26 \\
\hline & Overall & 38,89 & 63,13 \\
\hline
\end{tabular}

The results in Table 5 show that companies with high market value in all social sustainability categories have higher score than the companies with low market value. The biggest difference is seen in the category of occupational health and safety (OH). Companies with a market value of over 1 billion TL has the $\mathrm{OH}$ score of 88.89 , while the other group has the score of 41.67 . It has also been found that in the bribery-corruption (BC) and education (ED) categories, the difference between groups is about two times. On the other hand, in the philanthropy category, due to the reasons mentioned above, the low scores are seen in both groups.

Figure 3 is particularly striking in terms of the relevance of companies' social sustainability scores to market values. The $X$ axis represents the social sustainability level of companies. On the $Y$ axis, the market values of the companies are in logarithmic value. When each company is plotted on the social sustainability score and the market value, a remarkable relationship is observed.

Figure 3: Social Sustainability Score and Market Value Graph of Companies

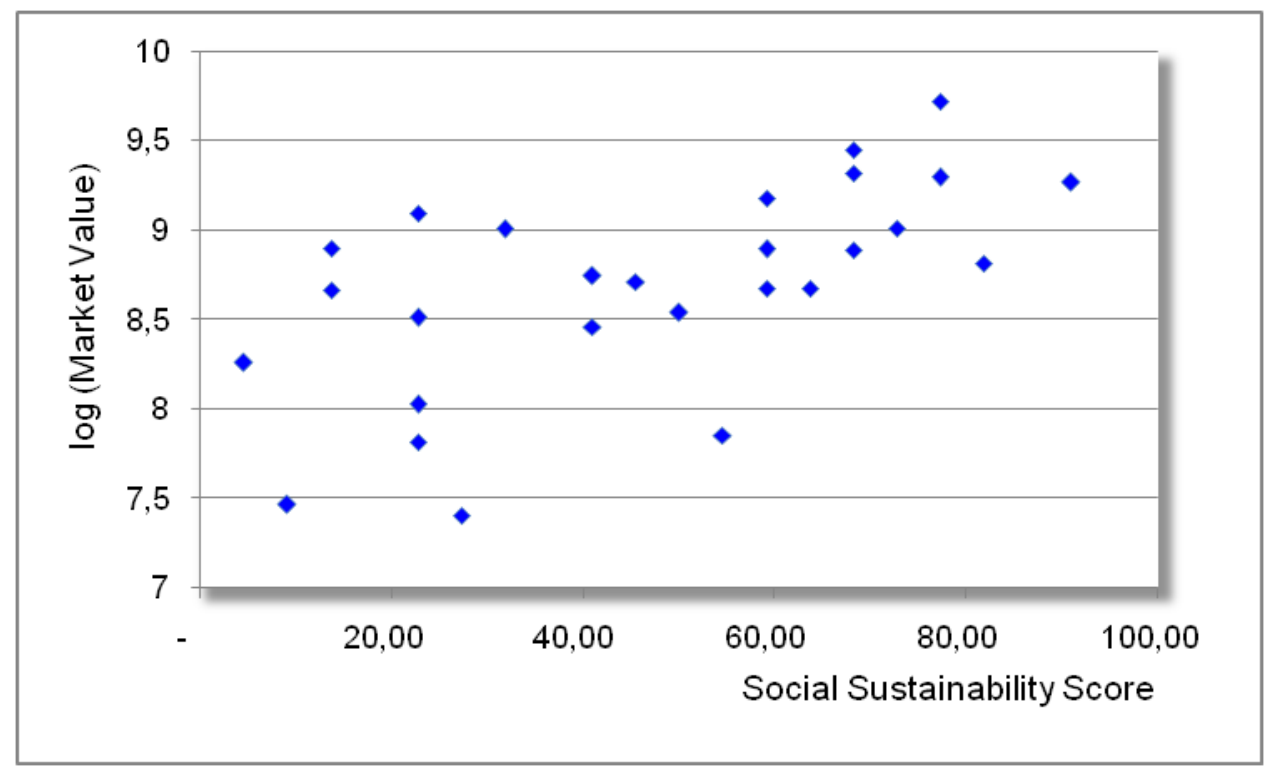

In Table 6, social sustainability scores are presented on both criteria and market values. In the overall column, the relevant criteria scores are given for the entire industry. The highest criterion score is the HR1 variable in the human rights category. This is followed by the HR2 variable in the same category and the $\mathrm{OH} 1$ variable in the occupational health and safety category. The lowest criterion score is the ED1 in the education category. These results, which are shown in Table 6, are analyzed one by one below.

In the criterion BC1, it is researched whether the companies disclose on "combatting bribery and corruption" issue in public sources. The score for this criterion is 51.85 . In the same category, the other criterion is questioned whether there is a antibribery policy and the score falls to 22.22. Especially companies which have low market value seem to be unable to create a policy in this regard. In developing countries such as Turkey, bribery and corruption issues are discussed in more state and government level. Bribery and corruption in private companies are unfortunately handled adequately. The scores can be interpreted as a consequence of this. 
The results of the HR1 criteria in the human rights category concern whether there is discrimination among employees. Gender discrimination (HR2) is considered as a separate criterion. The results of the two criteria can also be considered sufficient. As a critical issue in terms of social sustainability, it has been investigated child labor as a risk factor. Child labor is prohibited except in cases specified by law in Turkey. The criterion expressed by HR3 includes not only the companies themselves but also their suppliers. In the study, it is questioned whether the company has made a statement about this risk. It was determined that only $22.22 \%$ of the companies disclosed about this issue and the remaining $78 \%$ did not disclose child labor risk. Another result of the research shows that companies with more than 1 billion TL market value in all the criteria (HR1, HR2 and HR3) considered in the human rights category provide criteria higher than others.

Table 6: Results of Social Sustainability Scores Based on Criteria and Market Value

\begin{tabular}{lccc}
\hline \multirow{2}{*}{ Criteria Code } & \multicolumn{3}{c}{ Criteria Score } \\
\cline { 2 - 4 } & Market Value $<1$ billion TL & Market Value $>=1$ billion TL & Overall \\
\hline BC1 & 44,44 & 66,67 & 51,85 \\
BC2 & 11,11 & 44,44 & 22,22 \\
HR1 & 83,33 & 88,89 & 85,19 \\
HR2 & 77,78 & 88,89 & 81,48 \\
HR3 & 16,67 & 33,33 & 22,22 \\
ER1 & 66,67 & 77,78 & 70,37 \\
ER2 & 33,33 & 33,33 & 33,33 \\
ER3 & 27,78 & 66,67 & 40,74 \\
ER4 & 33,33 & 100,00 & 55,56 \\
ER5 & 27,78 & 55,56 & 37,04 \\
ET1 & 66,67 & 77,78 & 70,37 \\
ET2 & 50,00 & 77,78 & 59,26 \\
ED1 & 11,11 & 11,11 & 11,11 \\
ED2 & 44,44 & 88,89 & 59,26 \\
ED3 & 22,22 & 77,78 & 40,74 \\
PH1 & 22,22 & 22,22 & 22,22 \\
PH2 & 16,67 & 22,22 & 18,52 \\
OH1 & 72,22 & 100,00 & 81,48 \\
OH2 & 11,11 & 77,78 & 33,33 \\
PR1 & 0,00 & 55,56 & 18,52 \\
PR2 & 72,22 & 88,89 & 77,78 \\
PR3 & 44,44 & 33,33 & 40,74 \\
\hline
\end{tabular}

The issue of employee rights is addressed in five criteria. In the first three criteria, disclosures have been sought about whether the companies apply objective criteria in healthy working conditions (ER1), recruitment \& promotion (ER2) and compensation issues (ER3). The score for the variable ER1 is 70.37. In ER2 and ER3 criteria, these scores decrease to $33.33 \%$ and $40.74 \%$ respectively. According to the regulations in Turkey public companies are required to explain the remuneration principles of board members and executives. But at lower levels there is no such requirement. The low-scoring ER2 and ER3 criteria can be explained by this. The fourth criterion (ER4) that is sought in the employee rights category concerns whether or not concrete information on employee training and career development is presented. In the study it is not accepted vague expressions such as "we attach importance to improving the skills of our employees". Instead, detailed information such as "internal mentoring", "skill development", "determining the objective and taking the initiative" programs for employees are evaluated as more concrete data. In summary, it is seen that $55.56 \%$ of the companies covered by the ER4 criteria provide this criterion. The final criterion for employee rights concerns the public disclosure of the human resources policy (ER5), with a score of 37.04 . It has been determined that the companies which have high market value in terms of employee rights provide higher values in four criteria than others, and they are at the same level in a criterion. It is noteworthy that all of the companies with a market value of more than 1 billion TL, in particular, have worked seriously in the development of the training and abilities of employees, as expressed by ER4.

The results of the criteria in the ethics category are presented in Table 6. The disclosure of the code of ethics of the companies is expressed by the ET1 variable and it is seen that the score is realized as 70,37 . The second criterion in this respect is the existence of grievance mechanisms against unethical behavior (ET2). 59,26\% of the companies disclose that they establish such mechanisms. The issue of publishing the ethical rules of all public companies on corporate internet sites is taken place in the Capital Markets Board (CMB) Corporate Governance Communiqué in Turkey. The Communiqué states that, while not obliging companies to do so, the company must disclose the reasons for their failure to publish. There is no obligation to establish a 
mechanism against unethical behaviors. The difference between the two criteria in the ethics category can be explained by this. it is seen that the companies with higher market value pay more attention to the ethical issue and share it with the public.

In the education category, the score for the ED1 variable is 11.11, indicating that the vast majority of companies do not provide information about the level of education of their employees. In ED2 criterion, it is questioned whether the company cooperates with educational institutions and the score is 59.26. In this regard, it is seen that some companies cooperate with educational institutions in their research and development activities and some companies offer internships, education and other activities to high school and university students. Cooperation of companies with universities contributes to both sides, but it is also a matter to be considered in terms of achieving sustainable development at the macro level. The last criterion in this category is related to the numerical expression of the training given to employees (ED3). While the ED3 score in the companies with a market value of over 1 billion TL is 77.78, this score decreases to 22.22 in other companies.

As mentioned earlier, the philanthropy category is the lowest scored category in the sector. Disclosure of donations of public companies is mandated by regulations. In the context of this research, it has been seen that the donations made when the minutes of the general meeting of the companies are examined are stated as a separate item on the agenda of the general meeting. However, it has been found that companies generally disclose donations as a total amount without detail. As a social sustainability criterion, it has been researched whether these amounts are given in detail, and it is evaluated that the companies which explain donations as only total amount do not satisfy the criterion.

Occupational health and safety is not only a matter of social sustainability but also a matter of law. $81,48 \%$ of the companies have OHSAS 18001 certificate on occupational health and safety $(\mathrm{OH} 1)$ and mostly shared this document on their internet pages. It has been found that all of the companies which have above 1 billion TL market value provided this criterion. For other companies, the $\mathrm{OH} 1$ criterion score is 72.22. Numerical explanations about the work accidents of the companies are expressed by $\mathrm{OH} 2$ variable and it is determined that this score is 33.33 in the industry. The results can be interpreted as the fact that the companies avoided sharing information about the work accident with their stakeholders.

Companies are also responsible for the products and services they produce. This issue is represented by three criteria in the product responsibility category. In the criterion expressed by the PR1 variable, it was researched whether companies share the customer satisfaction survey results with their stakeholders. The results are noteworthy that no company with a market value of less than 1 billion TL provided this criterion. But for companies with a market value higher than 1 billion TL, the PR1 criterion score is 55.56. In the PR2 criteria, it was questioned whether the company disclosed quality documents. The results of this criterion can be evaluated adequately. In the PR3 criteria, it is related to the information security policy of the company. The industry average at this criterion was 40.74 . This result indicates that there are significant deficiencies in information security or personal data protection.

\section{CONCLUSION}

The social dimension of corporate sustainability has long been neglected compared to its economic and environmental components. In recent years it appears that interest in social sustainability has increased significantly. However, a most of the studies address only a few components of social sustainability, which can not fully define social issues. On the other hand, the number of studies dealing with social sustainability as a holistic approach is not sufficient. Therefore, this study aims to fill this gap in the literature.

The purpose of this research is to create a framework of social sustainability and to analyze the social sustainability level of the companies listed on Borsa Istanbul (BIST) in non-metallic mineral industry. The level of social sustainability is also analyzed according to the market values of the companies. In this context, social sustainability is addressed in 8 categories and 22 criteria. These categories consist of anti-bribery and anti-corruption, human rights, employee rights, ethics, education, philanthropy, occupational health and safety and product responsibility.

Results reveal that level of social sustainability is $\mathbf{4 6 . 9 7}$ in the non-metallic mineral industry sector in Turkey. Considering that the companies researched in the study are large companies with thousands of investors, hundreds of employees and millions of dollars in sales volume, it is easy to say that this level of sustainability is not adequate.

When the results are analyzed on a category basis, it is determined that the lowest score is in the philanthropy category. The companies have responsibilities not only for their shareholders but also for their stakeholders. Although not only in the nonmetallic mineral industry in general in Turkey appeared to be a growing interest in social responsibility, it is observed that these activities are not systematic. It is the right of all stakeholders, especially shareholders, to know where and how much donations are made by publicly listed companies.

The results show that there are significant inadequacies in the "combating bribery and corruption" and in "education" categories. Only $22 \%$ of companies have a policy to anti-bribery and anti-corruption. In the field of education, it is expected that 
collaboration with universities and systematic training of employees will contribute to development and economic sustainability.

It is determined that the highest level of compliance is achieved under the ethics category. $70 \%$ of the companies have published their ethical code on their corporate internet sites and announced it to the public. However, it is believed that more companies will benefit from the effectiveness of complaints mechanisms against unethical behavior. The fact that most of the companies involved in the research disclose that they do not discriminate on the basis of language, religion, race and gender among the employees can be interpreted as a positive result. However, the findings show that companies' concerns about child labour risk are not sufficient. All companies involved in the research are publicly listed companies and are strictly controlled. Therefore, it is estimated that they do not employ child labour. However, it is expected that companies should be more sensitive to the child labour risks of their suppliers.

The results indicate that $81.48 \%$ of companies have Occupational Health and Safety OHSAS 18001 certification. But only one third of them disclose the data about job accidents to their stakeholders. Similarly, more than $80 \%$ of companies do not share the results of customer satisfaction surveys. It is expected that transparency in all social sustainability criteria, not just these two issues, could make the companies more sensitive to the issues concerned.

In the study, the results are also analyzed by considering the market values of the companies. The average level of social sustainability in the sector is determined as 63.13 for companies with a market value above 1 billion TL, and 38.89 for companies with a market value below 1 billion TL. In all of the eight categories examined, it is determined that high-market valued companies have a higher social sustainability score than the others.

The most important contribution of this research to the literature is to give a new perspective by suggesting quantifiable indicators for social sustainability. The criteria and categories suggested in the research can be applied in various industries especially in developing countries. Expressing social sustainability quantitatively will help comparison of companies, industries and countries. It is expected that the research will shed light on researchers, companies, sector representatives and regulatory agencies that will study in the field of social sustainability. However, there are several limitations of the study. First, in this study only the non-metallic mineral industry was examined. Secondly, it should be noted that this study only covers one country (Turkey) as another limitation. Finally, only publicly traded companies are examined in the research. This is largely due to the fact that non-public companies do not have the obligation to prepare information such as the comprehensive activity report, corporate governance compliance report. In spite of the fact that the results of the study give us an idea about social sustainability level of the industry, the results should not be generalized because of these limitations. There are several potential areas for further study on social sustainability. By following the methodology in this study, more quantitative indicators can be developed. Furthermore, it is also recommended that future studies include more industries and more countries.

\section{REFERENCES}

Ahmadi, H. B., Kusi-Sarpong, S., Rezaei, J. (2017). Assessing the social sustainability of supply chains using Best Worst Method. Resources, Conservation \& Recycling, Vol.126, 99-106.

Bamgbade, J., Kamaruddeen, A., Nawi, M. (2017). Malaysian construction firms' social sustainability via organizational innovativeness and government support: the mediating role of market culture. Journal of Cleaner Production, Vol. 154 , 114-124.

BIST. (n.d.). Borsa Istanbul. Retrieved from http://www.borsaistanbul.com/en/home-page

CMB. (n.d.). Capital Markets Board or Turkey. Retrieved from http://www.cmb.gov.tr/

D' Amato, D., Li, N., Rekola, M., Toppinen, A., Lu, F.-F. (2015). Linking forest ecosystem services to corporate sustainability disclosure: a conceptual analysis. Ecosystem Services, Vol. 14 , 170-178.

Delai, I., Takahashi, S. (2013). Corporate sustainability in emerging markets: insights from the practices reported by the Brazilian retailers. Journal of Cleaner Production, Vol. 47 , 211-221.

Denizli Cam. (2018). Denizli Cam 2017 annual report. Retrieved from http://www.denizlicam.com.tr/tr/yatirimci-iliskileri/sunumlar-veraporlar/yillik-faaliyet-raporlari

Docekalová, M. P., Kocmanová, A. (2016). Composite indicator for measuring corporate sustainability. Ecological Indicators, Vol. 61 , 612-623.

Dyllick, T., Hockerts, K. (2002). Beyond the business case for corporate sustainability. Business Strategy and the Environment, Vol. 11, $130-141$.

Engida, T. G., Rao, X., Berentsen, P. B., Lansink, A. G. (2018). Measuring corporate sustainability performance - the case of European food and beverage companies. Journal of Cleaner Production, Vol. 195 , 734-743.

Freeman, R. (2010). Strategic management: a stockholder approach. NewYork: Cambridge University Press.

Friedman, M. (1982). Capitalism and freedom. Chicago: The University of Chicago Press. 
Glavič, P., Lukman, R. (2007). Review of sustainability terms and their definitions. Journal of Cleaner Production, Vol. 15 , $1875-1885$.

Global Reporting. (2018). About Global Reporting Initiative. Retrieved from https://www.globalreporting.org/information/aboutgri/Pages/default.aspx

Global Reporting. (2013). G4 Sustainability Reporting Guidelines Implementation Manual. Retrieved from https://www.globalreporting.org/resourcelibrary/GRIG4-Part2-Implementation-Manual.pdf

Hedberg, C.-J., von Malmborg, F. (2003). The Global Reporting Initiative and corporate sustainability reporting in Swedish companies. Corporate Social Responsibility and Environmental Management, Vol.10, 153-164.

Hutchins, M. J., Sutherland, J. W. (2008). An exploration of measures of social sustainability and their application to supply chain decisions. Journal of Cleaner Production, Vol. $16,1688-1698$.

KAP. (n.d.). Kamuyu aydınlatma platformu (Public Disclosure Platform). Retrieved from https://www.kap.org.tr/en/

Mani, V., Gunasekaran, A., Delgado, C. (2018). Supply chain social sustainability: standard adoption practices in Portuguese manufacturing firms. International Journal of Production Economics, Vol. 198 , 149-164.

Mani, V., Gunasekaran, A., Papadopoulos, T., Hazen, B., Dubey, R. (2016). Supply chain social sustainability for developing nations: evidence from India. Resources, Conservation and Recycling, Vol. 111 , 42-52.

McKenzie, S. (2004). Social sustainability: towards some definitions. Hawke Research Institute working paper series, No. 27 , 1-29.

Morelli, J. (2011). Environmental sustainability: a defiition for environmental professionals. Journal of Environmental Sustainability, Vol. 1 , 1-9.

Önce, S., Onay, A., Yeşilçelebi, G. (2015). Corporate sustainability reporting and situation in Turkey. Journal of Economics, Finance and Accounting, Vol. 2, No. 2 , 230-252.

Popovic, T., Barbosa-Povoa, A., Kraslawski, A., Carvalho, A. (2018). Quantitative indicators for social sustainability assessment of supply chains. Journal of Cleaner Production, Vol. $180,748-768$.

Pullman, M. E., Maloni, M. J., Carter, C. R. (2009). Food for thought: social versus environmental sustainability practices and performance outcomes. Journal of Supply Chain Management, Vol. 45, No. 4 , 38-54.

Salzman, O., Ionescu-Somers, A., Steger, U. (2005). The business case for corporate sustainability: literature review and research options. European Management Journal, Vol. 23, Issue 1 , 27-36.

Searcy, C., Elkhawas, D. (2012). Corporate sustainability ratings: an investigation into how corporations use the Dow Jones Sustainability Index. Journal of Cleaner Production, Vol. 35 , 79-92.

Skouloudis, A., Evangelinos, K., Kourmousis, F. (2010). Assessing non-financial reports according to the Global Reporting Initiative guidelines: evidence from Greece. Journal of Cleaner Production, Vol.18 , 426-438.

Statista. (2018). Major countries in worldwide cement production from 2012 to $2017 . \quad$ Retrieved from https://www.statista.com/statistics/267364/world-cement-production-by-country/

Toppinen, A., Li, N., Tuppura, A., Xiong, Y. (2011). Corporate Responsibility and strategic groups in the forest-based industry: exploratory analysis based on the Global Reporting Initiative (GRI) framework. Corporate Social Responsibility and Environmental Management, Vol. 19, $191-205$.

UN. (2016). Sustainable development goals. Retrieved from https://www.un.org/sustainabledevelopment/sustainable-development-goals/

Van Marrewijk, M. (2003). Concepts and definitions of CSR and corporate sustainability: between agency and communion. Journal of Business Ethics, 44 , 95-105.

WCED. (1987). Our common future: report of the World Commission on Environment and Development. Oxford: Oxford University Press. 
Appendix 1: List of Companies Covered by the Research

\begin{tabular}{|c|c|c|c|}
\hline BIST Code & Company & Total Assets (TL) & Market Value (TL) \\
\hline $\begin{array}{l}\text { ADANA, ADBGR, } \\
\text { ADNAC }\end{array}$ & ADANA CIMENTO (A, B and C) & 1.166.984.719 & 1.016.812.764 \\
\hline AFYON & AFYON CIMENTO & 789.193.877 & 778.000 .000 \\
\hline AKCNS & AKCANSA & 1.916.195.842 & 2.082.944.100 \\
\hline ANACM & ANADOLU CAM & 4.183 .064 .000 & 1.972 .500 .000 \\
\hline ASLAN & ASLAN CIMENTO & 610.313 .346 & 2.788 .600 .000 \\
\hline BASCM & BASTAS BASKENT CIMENTO & 649.813 .051 & 323.635 .435 \\
\hline BTCIM & BATI CIMENTO & 2.234.190.774 & 790.400 .000 \\
\hline BSOKE & BATISOKE CIMENTO & 1.072.159.165 & 462.800 .000 \\
\hline BOLUC & BOLU CIMENTO & 777.105 .271 & 770.606 .075 \\
\hline BUCIM & BURSA CIMENTO & 872.751 .956 & 555.532 .992 \\
\hline CMBTN & CIMBETON & 116.038 .036 & 65.348 .400 \\
\hline CMENT & CIMENTAS & 1.567.200.000 & 1.009 .628 .080 \\
\hline CIMSA & CIMSA & 3.242.449.563 & 1.849.306.011 \\
\hline DENCM & DENIZLI CAM & 92.254 .381 & 71.220 .000 \\
\hline DOGUB & DOGUSAN & 21.304 .637 & 29.200 .000 \\
\hline EGSER & EGE SERAMIK & 421.956 .267 & 345.000 .000 \\
\hline GOLTS & GOLTAS CIMENTO & 775.127 .419 & 470.160 .000 \\
\hline IZOCM & IZOCAM & 331.704 .096 & 648.682 .741 \\
\hline KONYA & KONYA CIMENTO & 433.034 .171 & 1.242 .727 .200 \\
\hline KUTPO & KUTAHYA PORSELEN & 398.644 .311 & 286.203 .456 \\
\hline MRDIN & MARDIN CIMENTO & 334.704 .347 & 469.857 .960 \\
\hline NIBAS & NIGBAS NIGDE BETON & 67.608 .395 & 25.380 .000 \\
\hline NUHCM & NUH CIMENTO & 1.751.892.336 & 1.497.629.592 \\
\hline TRKCM & TRAKYA CAM & 8.021 .325 .000 & 5.220 .600 .000 \\
\hline USAK & USAK SERAMIK & 510.307 .076 & 106.173 .031 \\
\hline UNYEC & UNYE CIMENTO & 384.034 .452 & 514.119 .470 \\
\hline \multirow[t]{2}{*}{ YBTAS } & YIBITAS INSAAT MALZEME & 188.426 .834 & 182.000 .000 \\
\hline & TOTAL & 32.929.783.322 & 25.575.067.307 \\
\hline
\end{tabular}

Source: Created by the author based on the data published in BIST and KAP, at the end of 2017. 